\title{
PERAN KEPOLISIAN DALAM MENANGGULANGI TINDAK PIDANA PERJUDIAN TOTO GELAP (TOGEL) (Studi Kasus wilayah Hukum Kecamatan Siborongborong Kabupaten Tapanuli Utara)
}

Josfrada Hosen Nababan ${ }^{1}$, Saron Nita Simaremare², Baik Lumbantoruan³, Dona Fengk Siahaan4, Jhon Erwin Sinaga ${ }^{5}$

Universitas Sisingamangaraja XII Tapanuli Utara, Sumatera Utara, Indonesia Josfradanababan19@gmail.com, saronnitasimaremare@gmail.com,

Baiklumbantoruan84@gmail.com, Donasiahaan15@gmail.com, Erwin789ong@gmail.com

\begin{tabular}{ll}
\hline & \\
\hline Received: & $12-02-2022$ \\
Accepted: & $12-02-2022$ \\
Published: & $20-02-2022$ \\
Keywords: & $\begin{array}{l}\text { gambling, lottery, } \\
\text { countermeasures, } \\
\text { policing }\end{array}$
\end{tabular}

\section{Abstract}

The purpose of this study was to determine the role of the police in tackling the crime of togel gambling (Toto Gelap) in the Siborongborong community and what obstacles were experienced by the police in tackling the criminal act of testing. This type of research is a qualitative research that uses a case study research design and descriptive research methods. The data collection technique in this study uses primary and secondary data sources by means of interviews, literature studies and documentation. purposive sampling, namely data collection based on the considerations of the researcher in accordance with the research objectives. The results and discussion of this study indicate that lottery gambling is a community disease that is jointly tackled by the community and the police through pre-emptive, preventive and repressive efforts. The role of the police in tackling lottery gambling is by conducting socialization, patrolling, monitoring, placing banners, receiving information from the public, investigating, arresting and detaining gamblers, investigating and submitting criminal reports. Players still often experience obstacles, both internal and external obstacles, so that the prevention of the crime of lottery gambling in the jurisdiction of Siborongborong, North Tapanuli Regency has not been maximized.

\begin{tabular}{ll}
\hline Kata & perjudian, togel, \\
kunci: & penanggulangan, \\
& kepolisian
\end{tabular}

Abstrak

Tujuan penelitian ini adalah untuk mengetahui peran kepolisian dalam menanggulangi tindak pidana perjudian togel (Toto Gelap) di masyarakat siborongborong dan kendala apa yang dialami oleh kepolisian dalam menanggulangi tindak pidana perujian tersebut.Penelitia dilaksanakan di wilayah Hukum siborongborong dengan subjek prnelitian Polsek Siborongborong dan Tokoh Adat. Jenis penelitian ini adalah Penelitian kualitatif yang menggunakan desain penelitian studi kasus dan medode penelitian deskroptif.Teknik pengumpulan data dalam penelitian ini menggunakan sumber data primer dan sekunder dengan cara wawancar,studi pustaka dan dokumentasi. 
Josfrada Hosen Nababan, Saron Nita Simaremare, Baik Lumbantoruan, Dona Fengk

Siahaan, Jhon Erwin Sinaga

Peran Kepolisian dalam Menanggulangi Tindak Pidana Perjudian Toto Gelap (Togel) (Studi

Kasus Wilayah Hukum Kecamatan Siborongborong Kabupaten Tapanuli Utara)

Jenis wawancara dalam penelitian ini adalah wawancara tersruktur dan dilakukan dengan teknik purposive sampling yaitu pengambilan data dengan didasarkan pada pertimbangan peneliti sesuai dengan tujuan penelitian. Hasil penelitian dan pembahasan penelitian ini menunjukkan bahwa perjudian togel merupakan penyakit masyarakat yang di tanggulangi bersama oleh masyarakat dan kepolisian melalui upaya preemtif,preventif ,represiv.Peran kepolisian dalam menanggulangi perjudian togel adalah dengan melakukan sosialisasi ,patroli, pengawasan,pemasangan spanduk,penerimaan informasi dari masyarakat,penyelidikan,penangkapan dan penahanan pelaku perjudian, penyidikan, dan penyerahan berita acara pidana. Dengan penanggulangan yang dilakukan masih sering mengalami hambatan-hambatan,baik hambatan internal maupun hambatan eksternal,sehingga penanggulangan tindak pidana perjudian togel di wilayah hukum siborongborong,Kab.Tapanuli Utara belum maksimal.

Corresponding Author: Josfrada Hosen Nababan E-mail: Josfradanababan19@gmail.com

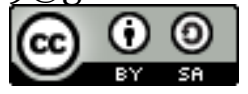

\section{PENDAHULUAN}

Negara Indonesia adalah Negara hukum, maka segala perbuatan masyrakat sudah diatur dan segala tatanan perilaku atau kegiatan masyarakat sudah ada norma norma hukum yang mengatur nya (Hayat, 2015).

Salah satunya kegiatan perjudian sudah merupakan hal fenomena yang tidak dapat dipungkiri ditemukan di masyarakat. Seiring dengan perkembangan zaman, perjudian dapat dilakukan dengan berbagai mekanisme dan ragam bentuk. Berjudi secara umum dipandang sebagai sebuah kejahatan. Tindak pidana berjudi atau turut serta berjudi pada mulanya telah dilarang dalam ketentuan pidana Pasal 542 KUHP namun berdasarkan ketentuan yang diatur dalam Pasal 2 ayat (4) dari UU No. 7 tahun 1974 tentang penertiban perjudian, telah diubah sebutannya menjadi ketentuan pidana yang diatur dalam Pasal 303 KUHP (Lamintang, 1990).

Prinsip bermain judi sebagaimana ditetapkan di dalam Pasal 303 KUHP diartikan sebagai tiap-tiap permainan, yang kemungkinan akan menang pada umumnya bergantung kepada untung-untungan saja, juga kalau kemungkinan akan menang itu bertambah besar karena si pemain lebih pandai atau lebih cakap. Main judi meliputi juga segala perjanjian pertaruhan tentang keputusan perlombaan atau permainan lain yang tidak diadakan oleh mereka yang turut berlomba atau main itu, demikian juga segala pertaruhanlainnya (Prodjodikoro, 1986).

Seiring dengan perkembangan teknologi dan informasi yang kian pesat, kegiatan berjudi pun mengalami peralihan ke judi online yang lebih praktis dan lebih aman dilakukan. Fenomena judi online yang sekarang marak terjadi adalah judi togel online, yang banyak sekali ditemukan di tengah masyarakat terutama di warung-warung internet, atau dengan menggunakan laptop dalam menjalankan aktivitas tersebut, atau bahkan lewat smartphone yang memiliki fasilitas pendukung atau aplikasi pendukung bermain judi togel online (Azis, Warman, \& Waty, 2013).

Prinsip dalam berjudi secara umum adalah sama yakni bertujuan untuk mendapat keuntungan jika menang taruhan (Anggreini, 2018). Semakin besar uang atau barang yang dipertaruhkan harganya akan semakin besar pula uang yang didapat. Judi togel (toto gelap) 
Josfrada Hosen Nababan, Saron Nita Simaremare, Baik Lumbantoruan, Dona Fengk

Siahaan, Jhon Erwin Sinaga

Peran Kepolisian dalam Menanggulangi Tindak Pidana Perjudian Toto Gelap (Togel) (Studi

Kasus Wilayah Hukum Kecamatan Siborongborong Kabupaten Tapanuli Utara)

merupakan judi yang banyak dijumpai. Judi ini dilakukan yaitu dengan cara menebak dua angka atau lebih. Bila tebakannya tepat maka pembeli mendapatkan hadiah beberapa ratus atau ribu kali lipat dari jumlah yang dipertaruhkan (Moeljatno, 2021).

Salah satu kemudahan yang ditemukan dalam judi online adalah dapat dimainkan kapan saja dan dimana saja sebab bandar-bandar judi online yang tersebar di internet beroperasi selama 24 jam, selain itu permainan ini dajalankan di warnet, tempat-tempat berwifi, atau melalui smartphone (Santoso, 2021). Pembayaran transaksi juga sudah menggunakan sarana online dengan mengirimnya lewat M-Banking.

Dalam memenuhi peranan kepolisian dalam menghadapi tindak pidana perjudian togel, kepolisian memiliki peran untuk menjaga ketertiban dan keamanan masyarakat dan menegakkan hukum dalam masyarakat (Harahap, 2013). Secara umum penanggulangan perjudian toto gelap di wilayah hukum siborongborong dilakukan melalui tiga upaya yaitu pre-emperis, preventif, dan reprensif.

Perjudian secara hukum telah diatur dalam Pasal 303 KUHP. Berdasarkan Pasal 303

(3) KUHP dalam (Vijananda, Yuliartini, \& Mangku, 2021), yang disebut dengan permainan judi adalah:

Tiap-tiap permainan, dimana pada umumnya kemungkinan mendapat untung tergantung pada peruntungan belaka, juga karena pemainnya lebih terlatih atau lebih mahir. Disitu termasuk segala pertaruhan tentang keputusan perlombaan atau permainan lain-lainnya, yang tidak diadakan antara mereka yang turut berlomba atau bermain, demikian juga segala pertaruhan lainnya.

Perjudian togel yang dilakukan secara online, memenuhi definisi perjudian sebagaimana dimaksud dalam pasal tersebut sebab keuntungan hanya didasarkan pada peruntungan semata. Jenis permainan dalam judi togel online yang marak digemari adalah permainan 4D 3D 2D dengan mencoba menebak angka sesuai dengan kombinasi yang dipilih (Nugroho, 2019). Hal tersebut tentunya dilakukan secara online dengan memilih server dan tempat atau warnet yang dijadikan sebagai tempat berjudi. Selain mudah juga aman dari jangkauan pihak yang berwenang (kepolisian) daripada judi yang dilakukan secara konvensional. Inilah yang menjadikan judi togel online belum begitu efektif penanggulangannya. Berdasarkan uraian tersebut di atas, maka peneliti tertarik untuk mengambil penelitian dengan Judul "Peran Kepolisian dalam Penanggulangan Judi Togel (Studi Kasus di polsek Sektor kecamatan siborongborong).” Tujuan penelitian ini adalah untuk mengetahui peran kepolisian dalam menanggulangi tindak pidana perjudian togel (Toto Gelap) di masyarakat siborongborong dan kendala apa yang dialami oleh kepolisian dalam menanggulangi tindak pidana perujian tersebut.

\section{METODE PENELITIAN}

Menurut (Silalahi, 2009) metode penelitian merupakan suatu cara dan prosedur yang sistematis dan terorganisasi untuk menyelidiki suatu masalah tentu dengan maksud mendapatkan informasi untuk digunakan sebagai solusi atas masalah tertentu. Pentingnya metode penelitian berdasarkan pengertian tersebut maka metode deskriptif dipilih oleh peneliti dalam pelaksanaan penelitian ini.

Lokasi penelitian ini dilaksanakan di wilayah hukum Siborongborong khususnya Polsek Siborongborong yang beralamat di Jl.SM Raja Siborongborong, Kecamatan Siborongborong Kabupaten Tapanuli Utara Provinsi Sumatra Utara. Teknik pengumpulan data dalam penelitian ini, peneliti mengumpulkan data dari berbagai sumber data dari kegiatan observasi, hasil wawancara mendalam dengan informan, serta dokumentasi.

Langkah-langkah yang ditempuh oleh peneliti dalam melaksanakan analisis data adalah:

1. Reduksi Data

Pada langkah ini, peneliti melakukan seleksi data, memfokuskan data pada permasalahan yang dikaji, melakukan upaya penyederhanaan, melakukan abstraksi, dan melakukan transformasi. 
Josfrada Hosen Nababan, Saron Nita Simaremare, Baik Lumbantoruan, Dona Fengk

Siahaan, Jhon Erwin Sinaga

Peran Kepolisian dalam Menanggulangi Tindak Pidana Perjudian Toto Gelap (Togel) (Studi

Kasus Wilayah Hukum Kecamatan Siborongborong Kabupaten Tapanuli Utara)

2. Penyajian Data

Penyajian data adalah langkah mengorganisasi data dalam suatu tatanan informasi yang padat atau kaya makna sehingga dapat dengan mudah dibuat kesimpulan (Vijananda et al., 2021).

3. Kesimpulan dan verifikasi

Kegiatan analisis terakhir adalah dengan membuat kesimpulan. Kesimpulan yang dibuat adalah jawaban terhadap masalah riset. Kemudian kesimpulan yang dibuat diverifikasi, yang dimana verifikasi merupakan upaya membuktikan kembali benar atau tidaknya kesimpulan dengan kenyataan.

\section{HASIL DAN PEMBAHASAN}

\section{Hasil Penelitian}

\section{Deskripsi Lokasi Penelitian}

\section{a. Gambaran Umum Lokasi Penelitian}

Penelitian ini dilakukan di wilayah polisi sektor (Polsek) Kecamatan Siborong-borong Kabupaten Tapanuli Utara. Kecamatan Siborong-borong memiliki luas sebesar 279,91 km, dengan jumlah desa/ kelurahan sebanyak 21 terletak antara $2^{\circ} 12^{\prime} 55^{\prime \prime} L U, 98^{\circ} 58^{\prime} 34^{\prime \prime} \mathrm{TB}$.

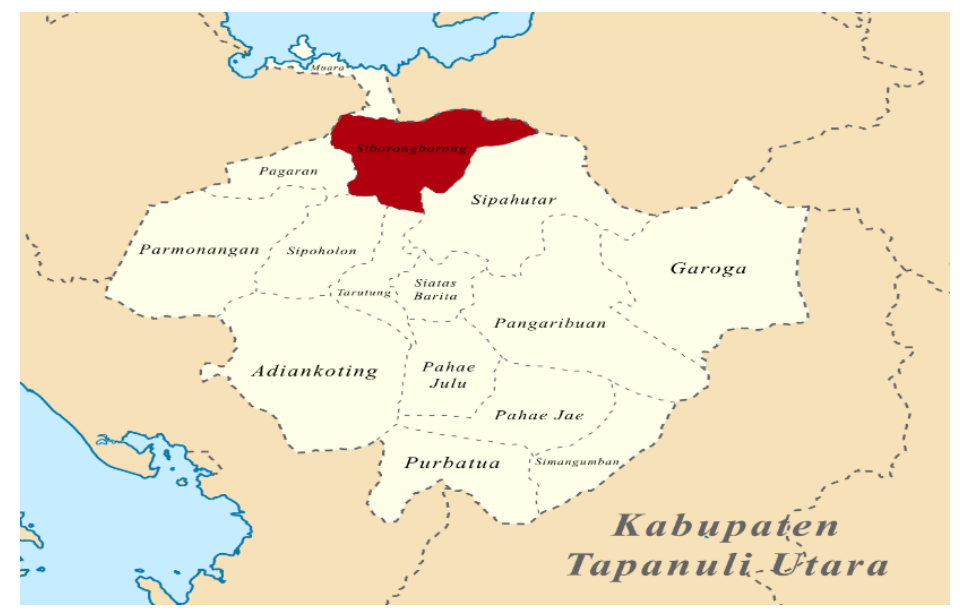

Gambar 1. Lokasi Penelitian

Kecamatan Siborong-borong merupakan salah satu dari 15 kecamatan di kabupaten Tapanuli Utara dengan batas wilayah: sebelah Utara berbatasan dengan kecamatan Muara dan Kabupaten Tobasa, sebelah barat berbatasan dengan kecamatan Pagaran sebelah selatan berbatasan dengan kecamatan Sipoholon dan Kecamatan Tarutung, sebelah timur berbatasan denga kecamatan Sipahutar.

Polisi sektor (Polsek Siborong-borong adalah sebuah institusi kepolisian yang berada di jajaran kepolisian Resort Tapanuli Utara (polres Taput). Wilayah hukum Polsek Siborongborong mencakup 21 desa/ kelurahan yaitu,Desa Bahal Batu I, Bahal Batu II, Bahal Batu III, Desa Hutabulu ,Desa Lobi Siregar I ,Lobi Siregar II, Desa Lumban Tonga- tonga, Desa Paniaran, Desa Parik Sabungan ,Desa Pohan Jae, Desa Pohan Julu,Desa Pohan Tonga, Desa Siaro, Desa Siborong-borong I, Desa Siborong-borong II, Desa Sigumbang, Desa Silait - lait, Desa Sitabo -tabo, Desa Sitabo -tabo Toruan, Desa Sitampurung dan Kelurahan Pasar Siborong-borong.

b. Visi Polsek Siborong-borong

Terwujudnya postur Polri khususnya Polsek Siborong-borong yang profesional, bermoral,modern sebagai pelindung,pengayom, dan pelaya masyarakat serta sebagai aparat penegak hukum yang profesional dan proporsional serta menghormati HAM yang terpercaya dalam memelihara Kamtibnas dan menegakkan hukum. 
Josfrada Hosen Nababan, Saron Nita Simaremare, Baik Lumbantoruan, Dona Fengk

Siahaan, Jhon Erwin Sinaga

Peran Kepolisian dalam Menanggulangi Tindak Pidana Perjudian Toto Gelap (Togel) (Studi

Kasus Wilayah Hukum Kecamatan Siborongborong Kabupaten Tapanuli Utara)

c. Misi Polsek Siborong-borong

1. Memberikan perlindungan pengayoman dan pelayanan masyarakat secara reponship dan tidak diskriminatif.

2. Pemberian perlindungan pengayoman baik pelayanan kepada masyarakat sepanjang waktu di wilayah hukum Polsek Siborong-borong.

3. Mampu memfasilitasi pemeliharaan Kamtibnas dilingkungan Polsek Siborongborong.

4. Polsek Siborong-borong harus mampu mengembangkan Polmas yang berbasis kepada masyarakat patuh hukum.

5. Polsek Siborong-borong menegakkan supremasi hukum secara profesional objektif, proporsional, transparan dan dapat dipertanggungjawabkan guna menjamin kepastian dan keadilan.

6. Menggalang kebersamaan dengan tokoh masyarakat guna menumbuh, mengembangkan kesadaran dalam perangi terorisme.

d. Tugas Pokok Reskrim Polsek Siborong-borong

1. Menanggulangi tidak pinada melalu upaya penyidikan untuk kepentingan peradilan.

2. Melakukan pengawasan dan koordinasi terhadap Penyidik Pegawai Negari Sipil(PPNS).

3. Melaksanakan pengumpulan dan pengolahan data-data kriminalitas yang bersifat formal.

4. Melaksanakan pembinaan fungsi Reskrim yaitu resrese mobil, reserse umum, reserse narkotik, resrse uang palsu) pemalsuan fungsi identifikasi dan krimimalistik untuk meningkatkan dan mengembangkan pelaksanaan tugas reserse pada semua tingkat kesatuan.

\section{Tokoh Adat Deskripsi Hasil Penelitian}

Data yang diambil dari penelitian ini menggunakan teknik wawancara semi terstruktur yang dilakukan di wilayah hukum Polsek Muara. Wawancara dilakukan dengan teknik purposive sampling yaitu pengambilan data dengan didasarkan pada pertimbangan peneliti sesuai dengan tujuan penelitian kepada 7 informan, antara lain: AKP US Gultom (Polisi), Iptu OR Tambunan (Polisi), dan Bripka S Simamora (Polisi). Pdt. Patar Manalu (Tokoh Agama), St.Butong (Tokoh Agama). Maju Nababan (Tokoh Adat), Pukka Nababan (Tokoh Adat). Berikut hasil dari wawancara yang diperoleh dalam penelitian:

1. Bagaimana keberadaan perjudian Togel dalam masyarakat Siborongborongkeberadaan?

Berdasarkan hasil wawancara dengan AKP LS Gultom, perjudian togel dari dulu sampai sekarang masih kerap terjadi dalam masyarakat Siborongborong. Hal ini bisa kita dengan kasus yang masih terjadi di Siborongborong.

Kasus terakhir terjadi pada tanggal 22 Januari 2018 sekitar pukul 14.30 di Urat Nihuta Desa Hutabulu Kecamatan Siborongborong. Polisi melakukan penyelidikan terhadap perjudian togel saat mendapat informasi dari masyarakat. Dalam kasus ini ditemukan barang bukti uang, satu unit handphone Merk Nokia yang bertuliskan nomor pesanan serta 2 (dua) lembar kertas yang bertuliskan nomor pesanan.

Menurut tokoh adat Pukka Nababan dan Maju Nababan, bahwa dalam masyarakat Siborongborong memang masih ada dijumpai pelaksanaan perjudian togel, walaupun dalam belakangan ini karena banyak pelaku yang ditangkap oleh polisi, hal tersebut lebih dilakukan secara tertutup. Pukka Nababan menegaskan bahwa dulu saya masih ingat bahwa perjudian togel bisa dilakukan secara bebas di Japo tuak (kedai tempat minum tuak), tetapi sekarang tidak lagi.

Sedangkan berdasarkan hasil wawancara dengan Pendeta Patar Manalu, perjudian togel masih ada di masyarakat Siborongborong. Hal ini karena ada jemaat gereja yang ternyata ditahan karena melakukan perjudian togel. Dari ketiga pernyataan narasumber diatas, maka dapat disimpulkan bahwa perjudian togel masih terdapat di Kecamatan Siborongborong. 
Josfrada Hosen Nababan, Saron Nita Simaremare, Baik Lumbantoruan, Dona Fengk

Siahaan, Jhon Erwin Sinaga

Peran Kepolisian dalam Menanggulangi Tindak Pidana Perjudian Toto Gelap (Togel) (Studi

Kasus Wilayah Hukum Kecamatan Siborongborong Kabupaten Tapanuli Utara)

2. Faktor apakah yang menyebabkan masyarakat melakukan perjudian togel?

Berdasarkan hasil wawancara dengan AKP LS Gultom, perjudian togel terjadi karena adanya faktor-faktor yang mempengaruhi masyarakat. Faktor yang paling utama adalah karena faktor ekonomi. Bripka S Simamora engungkapkan seperti yang kita ketahui bahwa mayoritas masyarakat Siborongborong berprofesi sebagai petani, maka dari itu tidak stabilnya hasil pertanian dan harga dari hasil pertanian yang kadang tidak menentu membuat masyarakat kekurangan biaya dalam memenuhi kebutuhannya. Maka ada beberapa masyarakat nekat untuk melakukan perjudian togel dengan harapan menang supaya bisa memenuhi biaya kebutuhannya. Faktor lainnya adalah kurangnya kesadaran hukum dari sebagian masyarakat karena ada juga masyarakat yang melakukan perjudian togel dan dengan kemauannya sendiri atau dengan coba coba dengan harapan menang untuk memperoleh untung yang besar.

Mengenai faktor yang mempengaruhi, Pukka Nababan mengatakan bahwa masyarakat melakukan perjudian togel bisa disebabkan oleh faktor internal yakni pola pikir dari masyarakat, karena sebagian masyarakat berpikiran bahwa perjudian merupakan sebuah kebiasaan yang tidak merugikan orang lain karens uang yang dipakai sebagai taruhan adalah uangnya sendiri. Selain itu perjudian dilakukan bisa juga karena merupakan sebuah hobby, karena ada masyarakat yang merasa senang saat dia ikut dalam permainan perjudian togel. Perjudian togel bisa terjadi karena faktor ekstenal yaitu ekonomi masyarakat kita yang masih kurang. Hal tersebut membuat sebagian masyarakat berpikir untuk mengadu nasibnya dengan mempertaruhkan uang yang dimilikinya dalam perjudian togel. St Butong mengatakan bahwa keberadaan seseorang dalam sebuah kelompok bahkan juga bisa mempengaruhi seseorang melakukan perjudian togel, misalnya kita sebagai masyarakat batak setelah bekerja seharian di ladang, biasanya para bapak-bapak dan pemuda pergi minum tuak ke kedai. Dalam situasi tersebut tidak jarang seseorang mendapat tekanan dari teman yang sama-sama sedang minum di kedai untuk ikut berpartisipasi dalam perjudian togel.

Berdasarkan hasil wawancara dengan Pdt. Patar Manalu mengatakan bahwa faktor yang mempengaruhi masyarakat melakukan perjudian togel adalah faktor internal yaitu kurangnya penguasaan diri akan keinginan-keinginan praktis, dan masyarakat kadang tidak puas dengan apa yang dimilliki saat ini.

Maka dari berbagai pernyataan tersebut, maka dapat disimpulkan bahwa ada dua faktor besar yang menyebabkan seseorang melakukan perjudian togel yaitu faktor internal dan eksternal. Faktor eksternal merupakan faktor yang berasal dari luar diri seseorang, seperti ekonomi dan tekanan dari kelompok. Sedangkan faktor internal adalah faktor dari diri sendiri yang berupa kemauan untuk mencoba bermain judi, hobby dan pola pikir masyarakat.

3. Bagaimanakah tindakan kepolisian Siborongborong terhadap masyarakat pelaku perjudian togel?

Menurut Iptu OR Tambunan, kepolisian yang bertindak sebagai penegak hukum tentunya menertibkan pelaku perjudian togel melalui proses hukum sesuai dengan aturan yang berlaku di negara kita. Kepolisian harus menghindari upaya penertiban yang menimbulkan kekerasan atau kesalahan prosedur penangkapan yang tidak sesuai aturan.

Selain itu AKP LS Gultom mengatakan bahwa dalam menindak pelaku perjudian togel selain melakukan proses sesuai hukum, diupayakan juga bentuk pembinaan terhadap pelaku yang menekankan bahwa perjudian togel itu adalah perbuatan yang dilarang oleh negara. Bripka S Simamora kemudian mengatakan pembinaan ini dilakukan melalaui pendekatan agama, misalnya di Lapas juga sering dilakukan kebaktian dengan harapan mereka menyadari perbuatan mereka dan memperoleh pencerahan untuk memperbaiki diri.

Berdasarkan berbagai pernyataan tersebut maka dapat disimpulkan bahwa terhadap pelaku perjudian togel, kepolisian bertindak sebagai penegak hukum yang memproses kasus 
Josfrada Hosen Nababan, Saron Nita Simaremare, Baik Lumbantoruan, Dona Fengk

Siahaan, Jhon Erwin Sinaga

Peran Kepolisian dalam Menanggulangi Tindak Pidana Perjudian Toto Gelap (Togel) (Studi

Kasus Wilayah Hukum Kecamatan Siborongborong Kabupaten Tapanuli Utara)

sesuai dengan hukum yang berlaku dan mengupayakan pembinaan terhadap pelaku perjudian togel.

4. Bagaimanakah pemberian sanksi terhadap pelaku perjudian togel?

Dalam hal pemberian sanksi terhadap pelaku perjudian togel menurut Iptu OR Tambunan bahwa siapapun yang tertangkap sedang melakukan perjudian togel akan segera ditindak lanjuti untuk memberikan sanksi terhadap pelaku perjudian. Hal ini sebagai penerapan asas legalitas yang menentukan bahwa sesuatu perbuatan adalah terlarang dan diancam pidana bagi barang siapa yang melakukannya.

Menurut AKP LS Gultom dalam pemberian sanksi terhadap pelaku, kepolisian berpedoman pada undang-undang yang berlaku yakni pasal 303 ayat (1) dan (2) KUHP yang mengatur mengenai judi.

Menurut Pendeta Patar Manalu, sanksi sangat perlu untuk memberi efek jera bagi pelaku perjudian. Pihak gereja sebenarnya tidak membenarkan jika ada jemaat yang melakukan perjudian togel, akan tetapi dari pihak gereja memang tidak ada sanksi tegas apababila ada jemaat yang kedapatan bermain togel. Sebagai seorang pendeta hanya bisa "manogu-nogu" yang artinya mengarahkan dengan perlahan dan mengingatkan tentang kebenaran dari firman yang melarang perbuatan semacam itu.

Pukka Nababan juga menerangkan bahwa terkait dengan sanksi yang diberikan kepada pelaku perjudian togel dari tokoh adat tidak bisa memberi sanksi, akan tetapi jika sebuah perbuatan masyarakat bertentangan dengan masyarakat lain dan tidak mau dinasehati, biasanya masyarakat itu dikucilkan atau dijauhi karena dianggap mengganggu masyarakat lainnya.

Dari pernyataan diatas dapat disimpulkan bahwa pemberian sanksi terhadap perjudian togel dilaksanakan dengan asas legalitas dan berpedoman kepada undang-undang yang berlaku yakni pasal 303 KUHP.

5. Apakah sanksi yang diberikan memberikan efek jera bagi pelaku perjudian togel?

Menurut AKP LS Gultom telah memberikan efek jera bagi pelaku

perjudian togel karena hampir tidak ada masyarakat yang tertangkap dengan kasus yang sama, dalam hal ini perjudian togel. Sedangkan menurut Iptu OR Tambunan sanksi pidana ditujukan untuk memberi efek jera bagi masyarakat yang melanggar, akan tetapi jika ada masyarakat yang masih melakukan perjudian togel setelah diberi sanksi maka itu merupakan bentuk dari kurangnya kesadaran masyarakat itu untuk mematuhi aturan yang ada. Berdasarkan pernyataan diatas disimpulkan bahwa hukum atau sanksi yang diberikan bagi pelaku perjudian togel memberikan efek jera bagimasyarakat.

6. Bagaimana upaya yang dilakukan dalam menanggulangi tindak pidana perjudian togel?

Berdasarkan hasil wawancara dengan pihak kepolisian bagian reskri bapak oleh Iptu OR Tambunan mengenai penanggulangan perjudian togel mengatakan bahwa kepolisian bertindak untuk menangkap bandar dan pelaku perjudian togel serta menanggap juga orang bertugas sebagai tukang tulis.

Sementara AKP LS gultom mengatakan bahwa penanggulangan perjudian togel dalam masyarakat Siborongborong dilakukan dalam dengan tiga cara, yaitu pre-emtif, preventif dan represif. Cara-cara tersebut dilakukan oleh pihak kepolisian dengan tujuan mampu memberantas perjudian togel sampai ke akar-akarnya. Penanggulangan denggan cara preemtif yang dilakukan oleh kepolisian dengan melaksanakan sosialisasi dan penyuluhan hukum. Hal ini bertujuan untuk meningkatkan kesadaran hukum dari masyarakat. Upaya preventif merupakan upaya yang dilakukan kepolisian untuk mencegah perjudian, dalam hal ini kepolisian biasanya melakukan patrol, melakukan penyuluhan hukum, dan pemasangan spanduk tentang larangan perjudian togel. Sedangkan usaha represif dilakukan dengan cara mendapatkan informasi dari masyarakat, melakukan penyelidikan, menangkap pelaku perjudian, melakukan penyidikan dan menyerahkan berita acara pidana. 
Josfrada Hosen Nababan, Saron Nita Simaremare, Baik Lumbantoruan, Dona Fengk

Siahaan, Jhon Erwin Sinaga

Peran Kepolisian dalam Menanggulangi Tindak Pidana Perjudian Toto Gelap (Togel) (Studi

Kasus Wilayah Hukum Kecamatan Siborongborong Kabupaten Tapanuli Utara)

Berdasarkan kedua pernyataan tersebut diatas dapat disimpulkan bahwa dalam penanggulangan perjudian togel, kepolisian Siborongborong menempuh tiga cara yaitu preemtif, preventif dan represif.

7. Bagaimana upaya yang dilakukan untuk mencegah terjadinya perjudian togel?

Menurut Pukka Nababan, upaya pencegahan sangat perlu dilakukan untuk mengantisipasi masyarakat yang tidak mengetaui efek dari perjudian togel tersebut. Sementara itu AKP LS Gultom menegaskan bahwa pencegahan perjudian togel telah dilakukan oleh pihak kepolisian Siborongborong dengan memantau dacrah yang rawan melaksanakan perjudian togel. Selain itu aparat kepolisian juga melakukan pengawasan terhadap lapo tuak yang ada di kecamatan Siborongborong. Aparat kepolisian dalam mencegah terjadinya perjudian togel juga melakukan koordinasi dengan masyarakat melalui tokoh adat dan tokoh agama serta melakukan razia di tempat yang rawan terhadap pelaksana perjudian togel.

Terkait dengan pencegahan perjudian togel menurut Pukka Nababan kepolisian telah melakukan sosialisasi di kantor camat, namun karena tidak semua masyarakat bisa ikut, kami tokoh adat yang ikut dalam sosialisasi mensosialisasikan kembali di kedai atau lapo tuak. Sebagai penatua atau tokoh adat kami memang masih bisa mangalean poda na uli (memberikan nasehat terbaik) dalam sebuah perkumpulan masyarakat.

Menurut Pendeta Patar Manalu pencegahan juga dilakukan dengan khotbah yang berisi bagaimana Tuhan juga melarang perbuatan perjudian. Hal ini juga dilakukan karena penyuluhan dan sosialisasi yang melibatkan tokoh agama sehingga tokoh agama juga bisa berpartisipasi dalam mencegah perjudian togel dengan memperkuat keyakinan agama dari jemaat. Dalam hal memperkuat keyakinan agama dari jemaat gereja sebenarnya sudah diupayakan dengan melaksanakan berbagai kegiatan rutin seperti partamiangan (kebaktian di rumah anggota jemaat) yang dilakukan rutin sekali seminggu di rumah anggota jemaat secara bergantian, kebaktian pemuda pada malam minggu yang dilakukan dengan tujuan para pemuda pemudi gereja memperoleh pengertian mengenai perbuatan baik dan tidak baik dalam kehidupan.

Berdasarkan berbagai pernyataan diatas maka dapat disimpulkan bahwa dalam mencegah perjudian togel di masyarakat, pihak kepolisian melakukan pemantauan, pengawasan terhadap masyarakat dan melakukan koordinasi dengan masyarakat termasuk tokoh adat dan tokoh agama.

8. Apakah jumlah personil kepolisian Siborongborong memadai dalam upaya penanggulangan perjudian togel?

Menurut AKP LS Gultom jumlah personil kepolisian Siborongborong ada sebanyak 31 orang. Kalau berbicara memadai, kami memaksimalkan kerja dari personil yang ada. Selagi kami memaksimalkan kinerja dari personil dan masih bisa menangani kasus yang ada kami rasa bisa dikatakan masih memadai. Berdasarkan pernyataan tersebut maka dapat disimpulkan bahwa personil kepolisian kurang memadai dalam melaksanakan penanggulangan perjudian togel.

9. Adakah kendala sarana prasarana dalam penanggulangan perjudian togeldi Siborongborong?

Menurut AKP LS Gultom, sarana prasarana yang sangat dibutuhkan dalam langkah penanggulangan perjudian togel adalah kendaraan seperti mobil patroli, sepeda motor. Jadi seperti yang kita lihat mobil patroli yang ada di kantor Polsek Siborong-borong hanya ada satu, jadi kemungkinan kepolisian sedikit kesulitan menggunakan mobil patroli dalam razia mengingat Siborongborong adalah wilayah kecamatan yang cukup luas. Selain itu Iptu OR Tambunan mengatakan meskipun terbatas dalam sarana prasarana, kepolisian biasa juga menggunakan kendaraan pribadi masing-masing dalam pelaksanaan tugas penanggulangan perjudian togel. Hal ini dilakukan karena lebih mengutamakan ketertiban dalam masyarakat 
Josfrada Hosen Nababan, Saron Nita Simaremare, Baik Lumbantoruan, Dona Fengk

Siahaan, Jhon Erwin Sinaga

Peran Kepolisian dalam Menanggulangi Tindak Pidana Perjudian Toto Gelap (Togel) (Studi

Kasus Wilayah Hukum Kecamatan Siborongborong Kabupaten Tapanuli Utara)

sesuai dengan visi kepolisian mewujudkan pelayanan keamanan dan ketertiban masyarakat yang prima.

Berdasarkan kedua pernyataan tersebut maka dapat disimpulkan bahwa sarana dan prasarana yang dimiliki oleh kepolisian memang terbatas namun tetap diupayakan untuk dalam rangka menjaga ketertiban dalam masyarakat.

10. Apakah masyarakat Siborongborong turut mendukung penanggulangan perjudian togel di Siborongborong?

Penanggulangan perjudian togel sangat memerlukan dukungan dari masyarakat. Menurut Iptu OR Tambunan bahwa masyarakat juga turut mendukung penanggulangan perjudian togel. Dengan mengikuti sosialisasi yang diadakan oleh pihak kepolisian dan turut membantu polisi dalam pegawasan perjudian merupakan bentuk dukungan dari masyarakat. Masyarakat dalam melakukan pengawasan juga melaporkan apabila mengetahui ada perbuatan perjudian togel yang meresahkan masyarakat.

Tokoh adat melalui Pukka Nababan mengatakan bahwa masyarakat turut mendukung penanggulangan perjudian togel dengan mengingatkan para masyarakat yang ingin mencoba melakukan perjudian togel denggan memberi nasehat. Sedangkan menurut Pendeta Patar Manalu, pihak gereja juga turut dalam upaya penanggulangan perjudian togel dengan "manogu tu dalan na dengan" atau mengarahkan ke jalan yang benar. Dalam upayanya, Maju Nababan mengatakan menggunakan pendekatan adat bisa juga mempengaruhi masyarakat mengingat masyarat juga masih memegang prinsip "Maradat" atau menjujung tinggi nasehat dari "natua-tua ni huta" atau penatua adat sehingga bisa diberi nasehat dengan umpasa-umpasa yang ada.

\section{Pembahasan Hasil Penelitian}

\section{Peran Kepolisian dalam Menanggulangi Perjudian Togel}

Upaya penanggulangan perjudian togel merupakan sebuah upaya untuk menghadapi dan mengatasi perjudian togel dalam masyarakat. Upaya penanggulangan untuk mengadapi perjudian togel sebagai salah satu penyakit dalam masyarakat dilakukan oleh setiap komponen yang terdapat di masyarakat Siborongborong. Penanggulangan perjudian togel dilakukan oleh masyarakat sebagai bagian dari warga negara yang berhak dan wajib dalam upaya pembelaan negara sebagaimana tercantum dalam UUD 1945 Pasal 27. Selain itu peran dari kepolisian menjadi sangat penting dalam penanggulangan perjudian togel sebagai bagian dari komponen masyarakat sebagai penegak hukum.

Dalam memeenuhi peran kepolisian dalam menghadapi tindak pidana perjudian togel, kepolisian memeiliki peran untuk menjaga ketertiban dan keamanan masyarakat dan menegakkan hukum dalam masyarakat. Secara umum, penanggulangan perjudian togel di wilayah hukum Siborongborong dilakukan melalui tiga upaya yaitu pre-emtif, preventif, dan represif.

Upaya pre-emtif adalah upaya awal yang dilakukan untuk mencegah terjadinya tindakan perjudian togel. Upaya pre-emtif ditujukan untuk meningkatkan kesadaran hukum masyarakat Siborongborong. Kepolisian Siborongborong dalam upaya pencegahan ini melakukan sosialisasi di berbagai tempat umum, dengan mengundang masyarakat atau perwakilan masyarakat dan di yang dilakukan secara berkala. Sosialisasi merupakan upaya dari pihak kepolisian sebagai proses untuk menyadarkan masyarakat mengenai efek bermain judi togel dan sanksi yang diterima apabila melakukan perjudian togel. Upaya sosialisasi, kepolisian Siborongborong melakukan kerja sama dengan tokoh adat dan tokoh agama untuk turut memberikan pemahaman kepada masyarakat terkait perjudian togel.

Upaya preventif dilakukan untuk memperkecil bahkan menutup kesempatan bagi masyarakat yang ingin melakukan perjudian togel. Dalam upaya preventif, Aepolisian memegang peran dalam:

1) Melakukan patroli

Kegiatan patroli merupakan kegiatan rutin yang dilakukan oleh kepolisian Siborongborong untuk memberikan rasa aman penertiban pada wilayah hukum 
Josfrada Hosen Nababan, Saron Nita Simaremare, Baik Lumbantoruan, Dona Fengk

Siahaan, Jhon Erwin Sinaga

Peran Kepolisian dalam Menanggulangi Tindak Pidana Perjudian Toto Gelap (Togel) (Studi

Kasus Wilayah Hukum Kecamatan Siborongborong Kabupaten Tapanuli Utara)

Siborongborong sesuai dengan misi kepolisian Siborongborong yaitu memberikan perlindungan pengayoman dan pelayanan masyarakat. Upaya yang dilakukan polsek Siborongborong ini memberikan dampak langsung bagi masyarakat karena setidaknya patroli ini memberikan peringatan bagi pelaku perjudian togel.

2) Melakukan pengawasan

Pengawasan merupakan tindakan kepolisian yang menurunkan aparat untuk mengawasi satu tempat yang rawan dalam melakukan perjudian togel. Pengawasan dilakukan untuk menghindari maraknya perjudian togel.

3) Pemasangan spanduk tentang larangan perjudian.

Peran kepolisian tersebut menjadi bagian dari upaya preventif yang turut didukung oleh masyarakat dengan partisipasi yang turut mengawasi perjudian togel. Dalam upaya preventif tersebut, tokoh adat dan tokoh agama terlibat dalam pengawasan terhadap masyarakat terkait dengan perjudian togel.

Upaya terakhir yang dilakukan dalam penanggulangan perjudian togel di wilayah hukum Siborongborong adalah upaya represif. Upaya represif merupakan upaya yang dilakukan pada saat terjadi tindak pidana perjudian togel. Penanggulangan tindak pidana perjudian dengan cara represif yaitu dengan menjatuhkan sanksi pidana pada barang siapa yang melakukan tindak pidana perjudian sesuai dengan peraturan hukum Dalam upaya represif, masyarakat memberikan informasi atau laporan kepada Polsek Siborongborong sebagai penegak hukum untuk dapat ditindak lanjuti. Penanggulangan tindak pidana perjudian togel yang dilakukan dengan cara represif yaitu dengan menjatuhkan sanksi pidana pada barang siapa yang melakukan tindak pidana perjudian sesuai dengan peraturan hukum.

Upaya represif yang dilakukan oleh Polsek Siborongborong antara lain: (a) informasi dari masyarakat, (b) penyelidikan, (c) penangkapan dan penahanan, (d) penyidikan, (e) menyerahkan berita acara pidana. Jadi, dalam upaya represif, Polsek Siborongborong setelah menerima informasi atau laporan dari masyarakat bahwa ada tempat yang telah dicurigai sebagai tempat melakukan perbuatan perjudian togel yang mengganggu keamanan dan ketertiban dalam masyarakat, aparat Polsek Siborongborong akan melakukan penyelidikan dan mendatangi langsung tempat tersebut. Apabila dijumpai bahwa terjadi perjudian togel maka polisi membekuk atau menangkap para pelaku penjudi. Setelah dilakukan penangkapan, para pelaku akan ditahan dan dilakukan penyidikan lalu menyerahkan berita acara pidana kepada pihak kejaksaan.

Upaya represif yang dilakukan oleh kepolisian Siborongborong pelaku perjudian togel akan diberikan sanksi menurut pasal 303 Ayat (1) KUHP Tentang Tindak Pidana Perjudian dengan hukuman penjara paling lama sepuluh tahun pidana atau denda paling banyak dua puluh lima juta rupiah dan pasal 303 bis KUHP dengan penjara paling lama empat tahun atau pidana denda sebanyak sepuluh juta rupiah. Sanksi hukum yang diberikan kepada pelaku perjudian lebih memberikan efek jera bagi pelaku perjudian togel karena menjamin kepastian hukum dengan menggunakan asas legalitas yang menentukan setiap tindak pidana diatur dalam Undang-Undang. Selain mendapat sanksi hukum, pelaku perjudian togel juga bisa mendapat sanksi sosial seperti "dikucilkan". Peran kepolisian dalam menanggulangi perjudian togel di wilayah hukum di Siborongborong melalui upaya preemtif, preventif dan represif telah dimaksimalkan dan terlihat dengan berkurangnya lapo tuak sebagai tempat judi di Siborongborong.

\section{Kendala dalam Penanggulangan Perjudian Togel}

Penanggulangan perjudian togel merupakan upaya kepolisian dalam menjaga kemanan dan ketertiban di dalam masyarakat. Hal ini adalah satu bentuk realisasi tugas pokok kepolisian yang diatur di dalam Undang-Undang Republik Indonesia Nomor 2 Tahun 2002 Tentang Kepolisian Negara Republik Indonesia yaitu: (Indonesia, 2002)

a. Memelihara keamanan dan ketertiban masyarakat

b. Menegakkan hukum

c. Memberikan perlindungan, pengayoman dan pelayanan kepada masyarakat. 
Josfrada Hosen Nababan, Saron Nita Simaremare, Baik Lumbantoruan, Dona Fengk

Siahaan, Jhon Erwin Sinaga

Peran Kepolisian dalam Menanggulangi Tindak Pidana Perjudian Toto Gelap (Togel) (Studi

Kasus Wilayah Hukum Kecamatan Siborongborong Kabupaten Tapanuli Utara)

Dalam pelaksanaan tugas penanggulangan perjudian togel, ditemukan kendala yang menghalangi atau membatasi kepolisian dalam menanggulangi perjudian togel. Berdasarkan hasil wawancara, ada kendala yang dijumpai dalam imenanggulangi perjudian togel di wilayah hukum Siborongborong. Kendala yang dihadapi oleh kepolisian dibedakan menjadi dua garis besar yaitu internal dan eksternal.

Kendala internal adalah kendala yang berasal dari pihak kepolisian, tokoh adat dan tokoha agama. Menurut hasil wawancara, kendala internal yang ditemukan dalam upaya menanggulangi perjudian togel adalah keterbatasan personil, waktu dan sarana prasarana yang ada. Menurut (d Simarmata, Gultom, \& Lubis, 2021) dalam pelaksanaan penanggulangan perjudian togel ini seringkali dirasakan kekurangan personil karena mengingat daerah kecamatan Siborongborong yang luas. Selain itu keterbatasan sarana prasarana juga menjadi kendala karena untuk melakukan patroli dan pengawasan menggunakan sarana yang dimiliki oleh kepolisian tidak akan maksimal, jadi tidak jarang juga para polisi melaksanakan tugasnya dengan menggunakan kendaraan pribadi. Hal ini menjadi satu kendala yang dihadapi polsek Siborongborong karena jika melakukan patroli dan pengawasan dilakukan satu tempat, maka kemungkinan informasi akan menyebar pada desa lain.

\section{KESIMPULAN}

Berdasarkan hasil temuan peneliti yang telah dilakukan dalam penelitian ini, maka diperoleh beberapa kesimpulan, antara lain:

1. Peran kepolisian Siborongborong dalam menanggulangi perjudian togel di wilayah hukum Siborongborong adalah dengan menjalankan pemeliharaan keamanan dan ketertiban dan menegakkan hukum dengan melakukan kerjasama dengan masyarakat dalam tiga upaya penanggulangan perjudian togel, yaitu upaya pre-emtif, preventif dan represif. Polsek Siborongborong berperan dalam penanggulangan perjudian togel dengan melakukan sosialisasi, patroli, pengawasan, pemasangan spanduk, penerimaan informasi dari masyarakat, penyelidikan, penangkapan dan penahanan pelaku perjudian, penyidikan, dan penyerahan berita acara pidana.

2. Adapun hambatan yang dialami dalam penanggulangan perjudian togel di wilayah hukum Polsek Siborongborong yaitu dalam upaya memeliharan keamanan di Siborongborong masih kurangnya personil kepolisian Polsek Siborongborong yang tidak sebanding dengan wilayah polsek Siborongborong yang cukup luas, keterbatasan sarana prasarana dan waktu yang dimiliki kepolisian dan tokoh masyarakat, adaya oknum kepolisian, tokoh Agama dan tokoh Adat yang melakukan diskriminasi terhadap pelaku perjudian togel, sulitnya mengungkap barang bukti, penyalahgunaan kemajuan IPTEK oleh masyarakat serta kurangnya kepedulian dan respon masyarakat terhadap penanggulangan perjudian togel.

Berdasarkan kesimpulan tersebut maka dapat ditarik kesimpulan akhir bahwa peran kepolisian dalam menanggulangi perjudian togel di wilayah hukum Shorongborong belum maksimal karena masih banyaknya kendala yang dijumpai dalam upaya penanggulangan perjudian togel.

\section{BIBLIOGRAFI}

Anggreini, Lusi. (2018). PERJUDIAN (Studi Sosiologi Tentang Perilaku Judi Togel di Kalangan Remaja Desa Mulyasari Kecamatan Sukamaju Kabupaten Luwu Utara). UNIVERSITAS NEGERI MAKASSAR. Google Scholar

Azis, Asrul, Warman, Edi, \& Waty, Nurmala. (2013). Perkembangan Hukum Mengenai Pemberantasan Judi Toto Gelap (Togel) dalam Perspektif Kriminologi. Jurnal Mahupiki, 1(1). Google Scholar

d Simarmata, Lewister, Gultom, Maidin, \& Lubis, Mhd Ansori. (2021). 
Josfrada Hosen Nababan, Saron Nita Simaremare, Baik Lumbantoruan, Dona Fengk

Siahaan, Jhon Erwin Sinaga

Peran Kepolisian dalam Menanggulangi Tindak Pidana Perjudian Toto Gelap (Togel) (Studi

Kasus Wilayah Hukum Kecamatan Siborongborong Kabupaten Tapanuli Utara)

PERTANGGUNGJAWABAN PIDANA BERUPA PEMBAYARAN RESTITUSI OLEH PELAKU TINDAK PIDANA PERDAGANGAN ORANG (TPPO). JURNAL RETENTUM, 2(1), 136-147. Google Scholar

Harahap, Elia Fatma. (2013). PERANAN POLRI DALAM MENANGGULANGI TINDAK PIDANA PERJUDIAN TOTO GELAP (TOGEL) DI KALANGAN MASYARAKAT (STUDI KASUS: POLSEK SUNGAI KANAN) KABUPATEN LABUHAN BATU SELATAN. UNIMED. Google Scholar

Hayat, Hayat. (2015). Keadilan Sebagai Prinsip Negara Hukum: Tinjauan Teoritis dalam Konsep Demokrasi. Padjadjaran Journal of Law, 2(2). Google Scholar

Indonesia, Republik. (2002). Undang-Undang Republik Indonesia Nomor 2 Tahun 2002 Tentang Kepolisian Negara Republik Indonesia. Lembaran Negara RI Tahun. Google $\underline{\text { Scholar }}$

Lamintang, P. A. F. (1990). Delik-delik khusus tindak pidana-tindak pidana melanggar norma norma kesusilaan dan norma-norma kepatutan. Mandar Maju. Google Scholar

Moeljatno, S. H. (2021). KUHP (Kitab undang-undang hukum pidana). Bumi Aksara. Google Scholar

Nugroho, Yudha Wahyu. (2019). ANALISIS PUTUSAN PENGADILAN NEGERI PONOROGO (NOMOR: 177/Pid. B/2016/PN Png.) STUDI KASUS TINDAK PIDANA PERJUDIAN ONLINE. Skripsi, Universitas Muhammadiyah Magelang. Google Scholar

Prodjodikoro, Wirjono. (1986). Tindak-tindak pidana tertentu di Indonesia. Eresco. Google $\underline{\text { Scholar }}$

Santoso, Aji Dwi. (2021). UPAYA KEPOLISIAN NEGARA REPUBLIK INDONESIA DALAM PENINDAKAN TINDAK PIDANA PERJUDIAN ONLINE (Studi Penelitian Di Polres Binjai). Kumpulan Karya Ilmiah Mahasiswa Fakultas Sosial Sains, 1(01). Google $\underline{\text { Scholar }}$

Silalahi, Ulber. (2009). Social research methods. Bandung, Refika Aditama. Google Scholar

Vijananda, I. Gede Damma, Yuliartini, Ni Putu Rai, \& Mangku, Dewa Gede Sudika. (2021). Implementasi Pasal 303 Kitab Undang-Undang Hukum Pidana Terkait Tindak Pidana Perjudian Cap Jiki Di Kabupaten Buleleng. Jurnal Komunitas Yustisia, 4(1), 22-34. Google Scholar 